IRA-International Journal of Management \& Social Sciences

ISSN 2455-2267; Vol.05, Issue 01 (2016)

Pg. no. 54-65

Institute of Research Advances

http://research-advances.org/index.php/RAJMSS

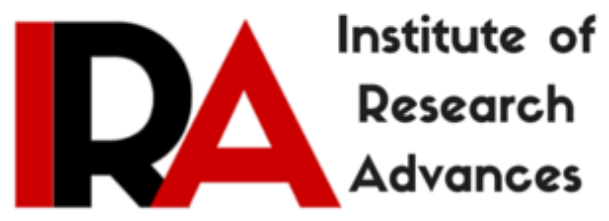

\title{
Spices Export from Kerala Current Trends \& Opportunities Ahead
}

\author{
${ }^{1}$ Ashish Bhatt \\ Assistant Professor \\ Parul Institute of Management, India. \\ 2 Jency Valasan \\ Researcher \\ Parul Institute of Management, India.
}

Type of Review: Peer Reviewed.

DOI: http://dx.doi.org/10.21013/jmss.v5.n1.p7

\section{How to cite this paper:}

Bhatt, A., \& Valasan, J. (2016). Spices Export from Kerala Current Trends \& Opportunities Ahead. IRA-International Journal of Management \& Social Sciences (ISSN 2455-2267), 5(1), 54-65. doi:http://dx.doi.org/10.21013/jmss.v5.n1.p7

(C) Institute of Research Advances

\section{(c) EY-NO}

This work is licensed under a Creative Commons Attribution-Non Commercial 4.0 International License subject to proper citation to the publication source of the work.

Disclaimer: The scholarly papers as reviewed and published by the Institute of Research Advances (IRA) are the views and opinions of their respective authors and are not the views or opinions of the IRA. The IRA disclaims of any harm or loss caused due to the published content to any party. 


\begin{abstract}
Changing eating habits and lifestyle of consumers across the globe have fuelled the demand for healthy food products, which has significantly highlighted the use of natural flavors, most of which come from spices. Being the largest producer and exporter of spices, India has immense growth potential. Technological advancement and research \& development are supporting the Indian spice exporters to offer high grade products to consumers globally.
\end{abstract}

Spices form an important part of virtually all recipes in all cultures, not only for their flavor and seasoning of foods but also for their numerous medicinal values. India produces a wide variety of spices including cardamoms, chilies, black pepper, mustard, coriander. Indian cuisine is also known for its rich taste which it derives from numerous spices. The demand of Indian spices is high in the global market due to their rich aroma, texture, and taste. India has the largest domestic market for spices in the world. The major importers of Indian spices are the US, China, Vietnam, the UAE and Malaysia. The primary spices imported from India are pepper, chili, turmeric, coriander, cumin, and fennel.

Growth of the spices market in India has been triggered by the establishment of quality evaluation laboratories that ensure the quality of the final product and make them world renowned. These labs stay in direct touch with the importers association of importing countries. Other factors contributing to the growth of the spices market is the infrastructural facilities provided by the Spices Board of India, and the shifting consumer interest from artificial to natural flavors. However, the market still faces a number of challenges in the form of food safety issues, and insufficiency of legal provisions, among others.

\title{
Introduction
}

Nature has blessed mankind with so many plants, out of which man has exploited some for his benefit to make his life enjoyable. Among them spices have made our life happier. Though required in small quantities, it has manifold properties and beneficial uses. Spices once hailed as 'gray gold' have played an important role in the history of civilization, exploration and commerce. Spices trade is the oldest known trade to man.

It was due to spices trade that ancient commercial ties existed between India and the Middle East. There had been a flourishing trade in spices successively between the Indians and the Greeks, the Romans, the Arabs, the Portuguese, the Dutch, the French and the British throughout the period of recorded history. According to Wendy Huttan (1998), "Fragrant cloves with their woody overtones, heady sweet cardamom, pungent black pepper, the nutmeg whose complex flavors burst forth when grated, all these and other aromatic seasonings of vegetable origin were once so highly priced, that they were literally counted out grain by grain". In recent years stiff competition has emerged between the spice producing countries. Developed countries have now put strict quality specifications on the import of spices. Though superior in quality, Indian spices are quoted at high prices in international markets because of the high cost of production and low productivity. India's prime position in the production and export of black pepper and cardamom has now been usurped by Vietnam and Guatemala respectively.

Within India, Kerala is the spice garden. Kerala is the leading producer of black pepper popularly called the 'King of spices', it enjoys a pride of place among all spices produced. Kerala is also the leading producer of Cardamom renowned as the 'Queen of spices', it is a tiny spice that attracted the consumers in the Orient and the Occident. More than 90 per cent of the production of black pepper 
and 70 per cent of the production of cardamom in the country is restricted to Kerala. But the spices trade in Kerala is now handicapped by a number of problems. Therefore, it is time for all those concerned with Indian spice industry to make earnest efforts to overcome the problems faced by the spices sector, or else our dominant position in the global spice market may be further relegated. Spices cultivation, which was once the monopoly of India has now spread to a number of other countries and the competition in spices trade, has become fierce. Though the mystery and rarity of spices have now virtually disappeared, their magical effect on food and their ability to delight the palate remain unchanged.

\section{Some of the Major Indian Spices are}

Table 1:- Major Indian Spices

\begin{tabular}{|c|c|}
\hline Asafoetida & It is a resin taken from a plant and is a pungent spice. \\
\hline Bay leaves & These are fragrant leaves with pointed ends are used in their dried form. \\
\hline Cardamom & $\begin{array}{l}\text { Cardamom has a sweet, lemony, eucalyptus flavor. It is world's second most } \\
\text { expensive spice. It is available as a powder, dried pods, or loose seeds. }\end{array}$ \\
\hline Cayenne pepper & It is a spice made from the seeds of plants in the capsicum family. \\
\hline Cinnamon & It is a sweet-tasting spice, with a warm, woody aroma. \\
\hline Cloves & $\begin{array}{l}\text { It is small, dried, reddish-brown flower bud of the tropical evergreen tree of } \\
\text { the myrtle family }\end{array}$ \\
\hline Tamarind & $\begin{array}{l}\text { It has a sour taste and very tart, citric flavor. It adds a distinctive cooling } \\
\text { quality }\end{array}$ \\
\hline Cokum & It has the same souring qualities as tamarind \\
\hline Coriander seeds & This spice tastes sweet and tangy, with a slightly citrus flavor \\
\hline Cumin & $\begin{array}{l}\text { The seeds are oval with ridges, greenish-beige in color, warm, nutty aroma } \\
\text { and a taste that is bitter }\end{array}$ \\
\hline Fennel & It has a sweet and aniseed flavor. \\
\hline Mustard seeds & $\begin{array}{l}\text { Hot flavor is released when it is mixed with water. The seeds can be put } \\
\text { whole into very hot oil and popped. }\end{array}$ \\
\hline Saffron & $\begin{array}{l}\text { It is the most expensive spice of all. It has a distinctively pungent, honey- } \\
\text { like flavor and aroma. }\end{array}$ \\
\hline Turmeric & It has a pungent, warm, earthy aroma and taste. \\
\hline $\begin{array}{l}\text { Nutmeg and } \\
\text { mace }\end{array}$ & $\begin{array}{l}\text { Mace is the fleshy lattice, covering of the nutmeg (hard nut), which is } \\
\text { golden brown in color. Nutmeg has more robust flavor than mace, but they } \\
\text { are otherwise very similar. They have nutty, warm and slightly sweet flavor. } \\
\text { Nutmeg is used to add sweet and savory flavor to dishes }\end{array}$ \\
\hline
\end{tabular}




\section{Star Anise Seed}

Star anise oil is a highly fragrant oil used in cooking, perfumery, soaps, toothpastes, mouthwashes, and skin creams.

\section{Uses of spices}

1. Spices are well-known appetizers or preservatives.

2. Many spices have rich medicinal properties and are used in pharmaceutical, perfumery, religious rituals, cosmetic products etc.

3. Spices are employed as adjuncts to import flavor and aroma or pungency to food.

4. Spice extracts are used to meet new demands of food processing industry.

5. Spices are employed in food industry in the preparation of pickles, biscuits, beverages, processed meat etc.

6. Spice oils and oleoresins are employed in cosmetics, tooth paste, toilet soaps, hair oils, tobacco products etc.

7. Spices find essential application in the preparation of Indian systems of medicines, as they have medicinal, preservative or antiseptic values.

8. Spices are used to season insipid food - their aromatic qualities are useful in overcoming the odors of bad food.

\section{Objective of study}

1. The major objective of the study is to evaluate Export of Spices from Kerala.

2. The specific objective of the study is: "To Study the Current Export Trends of spices from Kerala and opportunities ahead".

\section{Trends in the world:-}

Spices, being in the category of the high value agricultural products (HVAPs), have higher market values than the traditional cereal grains and export crops. Spices have now become an integral part of American, Continental, Arabic, Asian and Oriental cuisine. As a result of the worldwide spread of spices, no one country has been able to keep a monopoly of any particular spice.

Pepper dominates the world spice trade accounting for $30 \%$ of the spice trade in 2012 while cloves, cinnamon, nutmeg and mace, cardamoms, various other seeds, ginger and vanilla have a market share of less than $10 \%$ for each product group cardamom four per cent, ginger six per cent, turmeric eight per cent, tree spices fourteen per cent, seed spices fifteen per cent and capsicum twenty per cent. Almost all producing countries in spices are exporters also. All the leading countries of these products are developing or emerging economies except for vanilla and nutmeg and mace in which France, Germany and Netherland are within the top 3 exporters. Sri Lanka has a monopoly in Ceylon Cinnamon with $41 \%$ of world market share. Top 10 exporting countries have high concentration over geographical destinations.

The major markets in the global spice trade are the United States, the European Union, Japan, Singapore, Saudi Arabia and Malaysia. The principal supplying countries are China, India, Madagascar, Indonesia, Vietnam, Brazil, Spain, Guatemala and Sri Lanka.

\section{Trends in India}

India is said to be the oldest place where spices were available since time immemorial. Indian tropics have given spices like pepper, cardamom, chilli, turmeric, ginger, nutmeg, mace, basil, coriander, cassia, mustard, sea same, garlic and tamarind to the world. These spices are confined to different states. For example, black pepper is produced in Kerala, Karnataka and Tamilnadu, and the major cardamom growing states are Kerala, Karnataka, Sikkim and Tamilnadu. Turmeric is mostly confined to Andhra Pradesh and Tamilnadu. Likewise Andhra Pradesh, Maharashtra, Orissa and Tamilnadu are the major chili growing states, though chilli produced in Bihar is considered to be the most pungent. 
Ginger is produced mainly in Kerala and Meghalaya, while Andhra Pradesh and Rajasthan are the major producers of coriander.

The US is the major importer followed by China, Vietnam, the UAE, Malaysia, Saudi Arabia, the UK, Germany, Singapore and Sri Lanka. In 2014-15, India exported spices worth US\$ 2.42 million.

\section{Export trend of spices from India:-}

Table 2: Export trend of spices in India

\begin{tabular}{|l|l|l|l|l|l|}
\hline Item & $\mathbf{2 0 1 1 - 1 2}$ & $\mathbf{2 0 1 2 - 1 3}$ & $\mathbf{2 0 1 3 - 1 4}$ & $\mathbf{2 0 1 4 - 1 5}$ & $\mathbf{2 0 1 5 - 1 6}$ \\
\hline Pepper & 26700 & 15363 & 21250 & 21450 & 28100 \\
\hline Cardamom(S) & 4650 & 2372 & 3600 & 3795 & 5500 \\
\hline Cardamom(L) & 935 & 1217 & 1110 & 665 & 600 \\
\hline Chilli & 241000 & 301000 & 312500 & 347000 & 347500 \\
\hline Ginger & 21550 & 22207 & 23300 & 40400 & 24800 \\
\hline Turmeric & 79500 & 88513 & 77500 & 86000 & 88500 \\
\hline Coriander & 28100 & 35902 & 45750 & 46000 & 40100 \\
\hline Cumin & 45500 & 85602 & 121500 & 155500 & 98700 \\
\hline Celery & 3650 & 5171 & 5600 & 5650 & 5800 \\
\hline Fennel & 8100 & 13811 & 17300 & 11650 & 15320 \\
\hline Fenugreek & 21800 & 29622 & 35575 & 23100 & 33300 \\
\hline Other seeds & 13050 & 18442 & 27800 & 28250 & 23650 \\
\hline Garlic & 2200 & 22872 & 25650 & 21610 & 22500 \\
\hline Tamarind & 21395 & 17950 & 16000 & 13500 & 15350 \\
\hline Nutmeg \& Mace & 3620 & 3231 & 4450 & 4475 & 4050 \\
\hline Other Spices & 14505 & 16348 & 18700 & 23000 & 30150 \\
\hline Curry powder/Paste & 17000 & 17436 & 23750 & 24650 & 26550 \\
\hline Mint products & 14750 & 20039 & 24500 & 25750 & 21150 \\
\hline Spices Oils\& Oleoresins & 7265 & 9515 & 11415 & 11475 & 11635 \\
\hline Source - Spice Board Sats & & & & & Q \\
\hline
\end{tabular}

Source: - Spice Board Statics

Qty In Tonnes

Export trend of spices in Kerala:-

Historically, Kerala had contacts with the outside world, starting with the Babylonians as far back as 3000 B.C.E. Later, the Malabar Coast of Kerala witnessed the arrival of Arabs, Chinese, followed by European powers like the Portuguese, the French and the British. Most of them came for trade. And spices of Kerala invariably became the most traded commodity. Kerala is home to a variety of spices; and is also noted for producing some of the best quality when it comes to spices like cardamom and pepper. Irrespective of cultural, religious and other differences, spices occupy a special place in providing a unique flavor to the culinary specialties of Keralites. Spices still dominate the commodities trade in Kerala. Three-fourths of spice exports from India are sourced from Kerala

As of 2014-15, Kerala was the $2^{\text {nd }}$ largest producer of pepper in India, after Karnataka followed by Tamil Nadu. 


\begin{tabular}{|c|c|c|c|c|c|c|}
\hline \multicolumn{7}{|c|}{$\begin{array}{l}\text { ITEM-WISE EXPORT OF SPICES FROM KERALA (COCHIN AND TRIVANDRUM } \\
\text { PORTS) (QTY IN M.T) }\end{array}$} \\
\hline ITEM & $2010-11$ & 2011-12 & 2012-13 & 2013-14 & 2014-15 & $2015-16$ \\
\hline PEPPER & 16294.97 & 24016.94 & 13013.77 & 15858.04 & 16275.00 & 18555.00 \\
\hline CARDAMOM(SMALL) & 794 & 3611 & 1900 & 1920 & 1798 & 2888 \\
\hline GINGER & 2925 & 5962 & 3820 & 3239 & 2790 & 3406 \\
\hline TURMERIC & 7190.96 & 10350.17 & 8857.40 & 8643.94 & 9309.19 & 11917.00 \\
\hline NUTMEG \& MACE & 1372.05 & 2251.76 & 1810.79 & 2295.87 & 2196.33 & 2066.00 \\
\hline CHILLI & 19431.18 & 21568.42 & 21277.00 & 21136.61 & 22885.85 & 33740.00 \\
\hline CORIANDER & 2679.07 & 3030.28 & 2472.85 & 2586.97 & 2652.43 & 2985.00 \\
\hline CUMIN & 962.64 & 1282.48 & 1632.11 & 1531.33 & 1416.70 & 1445.00 \\
\hline CELERY & 593.55 & 497.24 & 230.67 & 346.76 & 275.65 & 244.00 \\
\hline FENNEL & 170.62 & 288.08 & 398.41 & 279.06 & 214.08 & 292.00 \\
\hline FENUGREEK & 653.68 & 763.84 & 774.22 & 710.42 & 736.13 & 680.00 \\
\hline GARLIC & 70.67 & 217.26 & 374.27 & 344.97 & 242.61 & 182.00 \\
\hline MINT PRODUCTS & 33.18 & 9.43 & 243 & 243.00 & 15.53 & 47.00 \\
\hline SPICE OILS \& OLERNES & 6754 & 6397 & 7517 & 8809 & 6982 & 6654 \\
\hline $\begin{array}{l}\text { CURRY } \\
\text { POWDER/MIXTURE }\end{array}$ & 6324 & 8098 & 6787 & 6225 & 7008 & 8067 \\
\hline OTHER SEED SPICES & 204 & 263 & 279 & 193 & 233 & 301 \\
\hline OTHER MISCE. SPICES & 7276 & 8465 & 8044 & 7048 & 6522 & 6607 \\
\hline
\end{tabular}

\section{Literature review}

(Prakash, 2008)Studied the farm crisis in Idukki district and found that labour shortage, fall in the prices of pepper; cocoa, coconut and other spices have triggered the farm crisis. He recommended that the Union Commerce Ministry should form a price control cell to regulate the prices of spices, coffee, tea rubber and coconut and curb imports.

(Thakamani, 2009) in his book 'Organic Spices' stated that the over use of chemicals, fertilizers and pesticides has ruined the mother earth, polluting food, drinking water and air. He suggested that organic mode of production is the only way to save ecology and environment, produce hazard- free food for the people and conserve natural resources. According to him, organic production is a commercially viable option for farmers, as organic food/products fetch a premium price at less cost of production as it avoids chemical fertilizers and pesticides.

(Leu, 2010)' reported that one of the advantages of organic farming is to improve soil health and productivity by increasing organic matter (carbon) levels, particularly humus. In doing so, organic farming can remove significant amount of carbon dioxide from the atmosphere. In contrast, some forms of conventional agriculture have caused a massive decline in soil organic matter, due to oxidizing organic carbon by incorrect tillage, the over use of nitrogen fertilizers and form top soil loss through wind and water erosion. According to him, soil carbon is one of the most neglected yet most important factors in soil fertility, disease control, water efficiency and farm productivity

\section{Research Methodology}

\section{Research Design}

* This is a descriptive research using survey approach.

\section{Source of Data}

* Primary Data was collected through online questionnaire.

* Secondary data was collected from the spices board \& various previous researches. 
Sample type: The response of this Questionnaire is based on convenience sampling

Sample Design: Snowball Sampling

Sample Frame: Directory of Spices Board

Sample Size: -17respondent from Kerala.

\section{Scope of the study}

$\checkmark \quad$ To collect and analyze the export trends of spices in Kerala. For this purpose secondary data from the published sources is collected.

$\checkmark$ To carry out market survey of current trends of export of Spices. Data is collected through a structured online questionnaire.

\section{Constraints \& Limitation of Study}

$\checkmark$ The statistical data were taken for last five years i.e. from 2010-11 to 2015-16, which may not generalize the results.

$\checkmark$ Sample size is small as some of the exporters and traders of spices did not cooperate with the data collection.

$\checkmark$ Some of the exporters and traders were unwilling to furnish the full details

\section{Data interpretation}

Principle Products Export Line

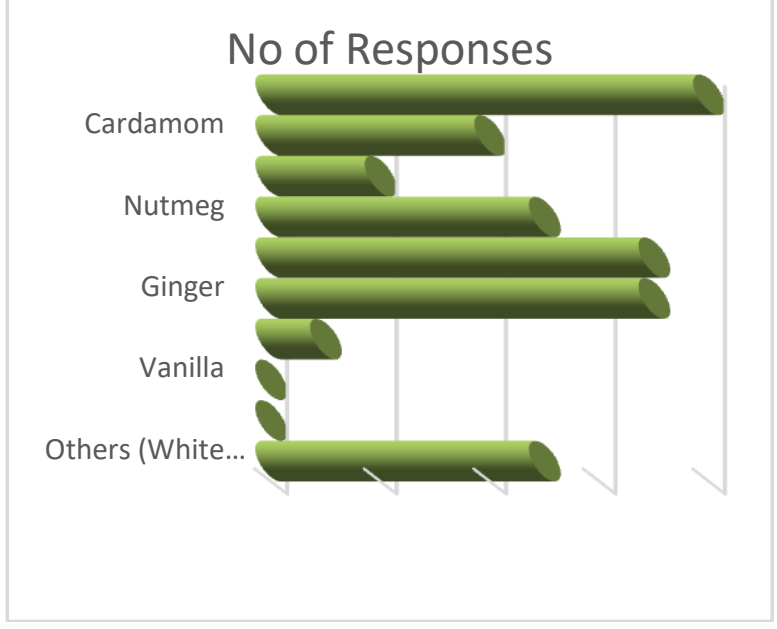

Major Countries for Export

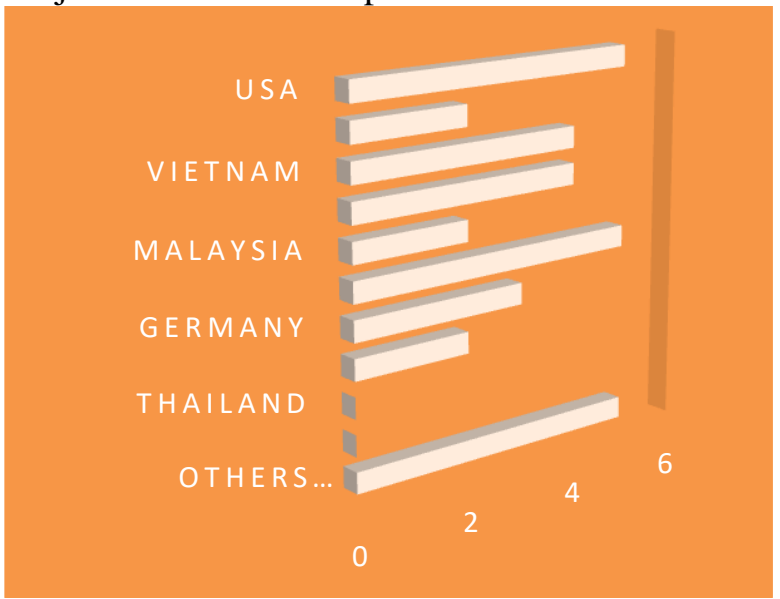

From the data it was inferred that all the exporters were exporting pepper, $87 \%$ where exporting both turmeric and ginger, $62 \%$ were exporting nutmeg, $50 \%$ were exporting cardamom, $25 \%$ were exporting clove $12 \%$ were exporting cinnamon, where as $62 \%$ were exporting other spices.

Majority of the respondents i.e.67\% exported spices to USA \& UK, $50 \%$ exported spices to Vietnam \& UAE, $38 \%$ exported spices to Germany, $25 \%$ exported spices to China, Malaysia \& Saudi Arabia, whereas $62 \%$ of exporters exported spices to other countries like Qatar, EU, Spain, Fiji, Mexico \& France. 
Sufficient Production Capacity

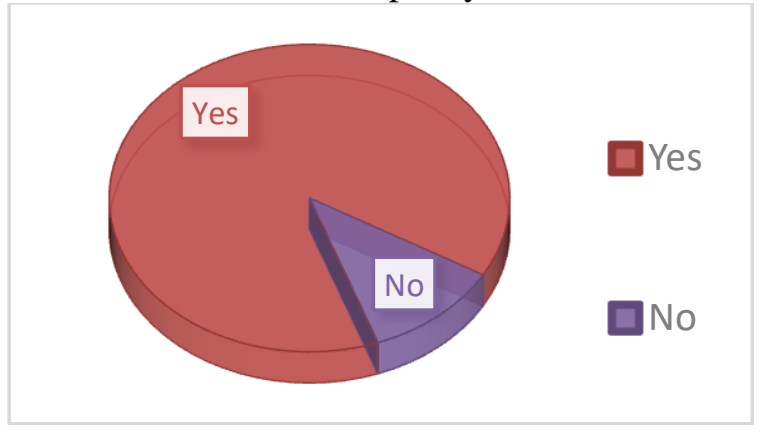

Dedicate Staff, Time \& Resource For Exports?

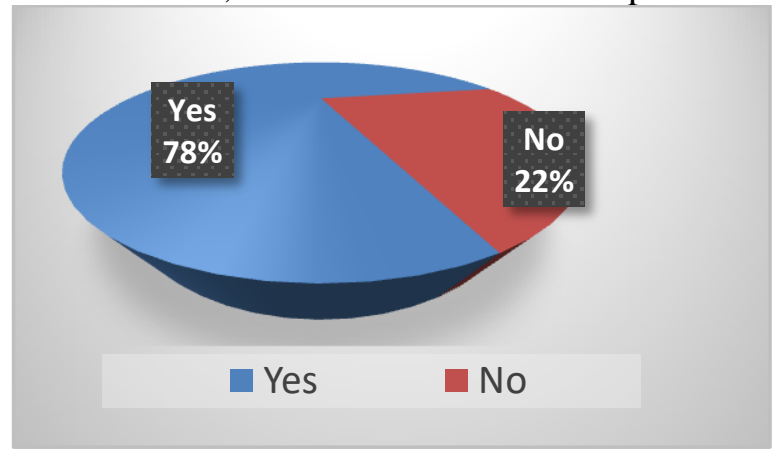

After the interpretation of the data it was found that majority respondents (i.e. $89 \%$ ) have sufficient production capacity that can be committed to export markets, while remaining $11 \%$ don't have.
From the data it was found that majority respondents, i.e. $78 \%$ have staff, time \& resource which can be dedicated for exports, whereas $22 \%$ of the respondents felt the inadequacy of resource and staff for exports.

Adequate Knowledge in Modifying Product Packing \& Ingredients Quality To Meet Foreign Export Regulations \& Cultural Preference

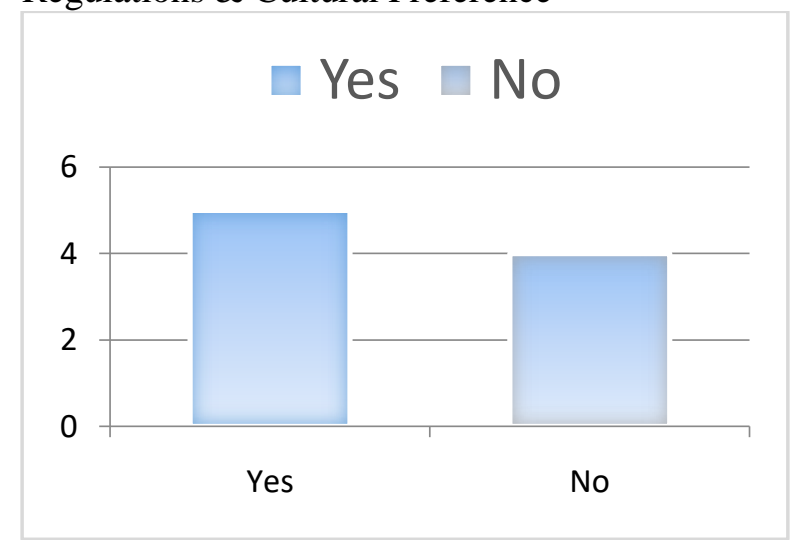

Of the total respondent $45 \%$ lacked adequate knowledge to modify product packing \& ingredients quality to meet the demands of foreign markets, the other $55 \%$ had adequate knowledge of the foreign export regulations $\&$ cultural preference.

Suggestions to Popularize Good Agricultural Practices (Gap)

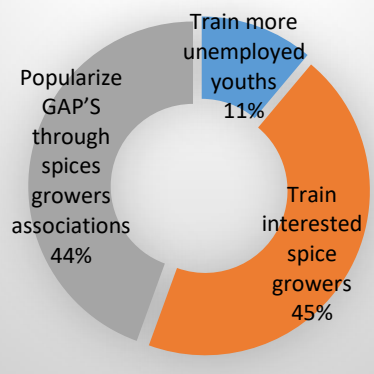

From the data it was found that majority respondents expect the government to train interested spice growers, while $44 \%$ feel the government should popularize GAP'S through spices growers associations whereas $11 \%$ expect the Government to train more unemployed youths. 
Approached any Institutes for Agricultural Related Problems and response
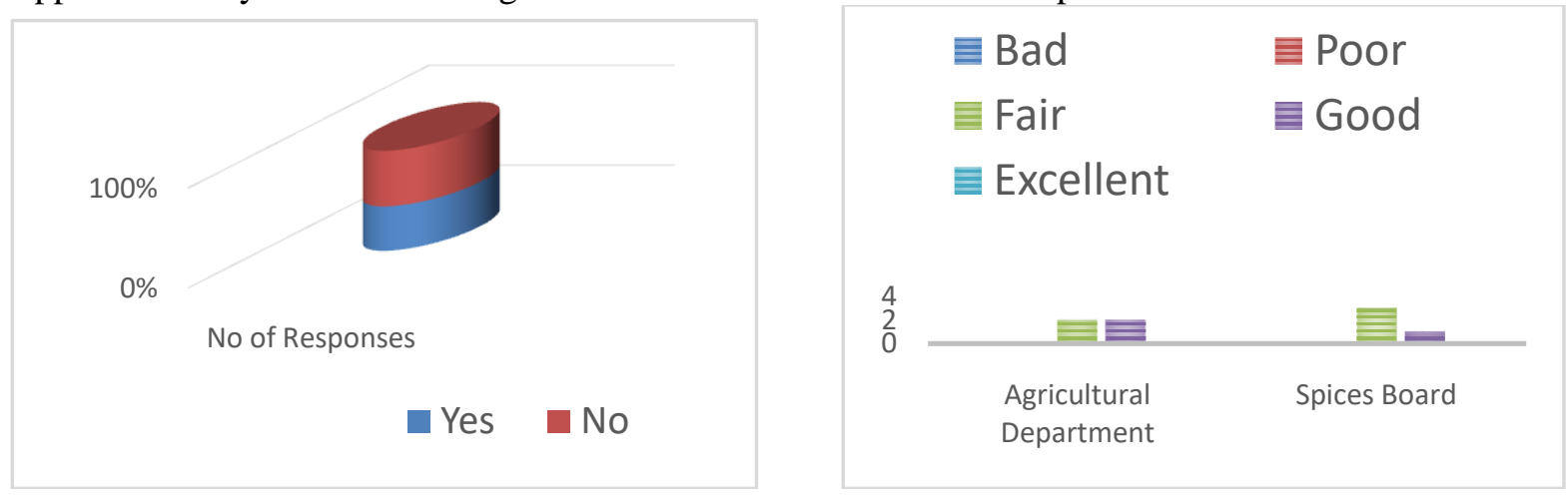

From the above data we inferred that majority of manufactures (56\%) have never approached the departments, only $50 \%$ of those that approached Agricultural department rate their service as good and the remaining $50 \%$ rated it as fair whereas $75 \%$ of those that approached the spices board rate their service as fair and the remaining $25 \%$ rated it as fair.

\section{The Policies That Should Be Introduced That Would Help Exporter}

Only $33 \%$ of respondents choose to answer this question, according to them there should be a uniform organic certification process, the government should provide more facilities for exports \& the spices board should initiate more awareness drives in spice growing districts.

\section{Training Programme}

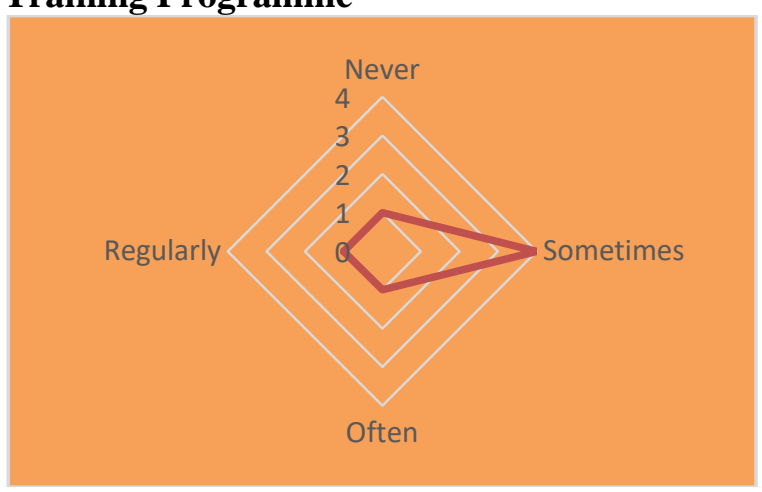

\section{Increment in Export}

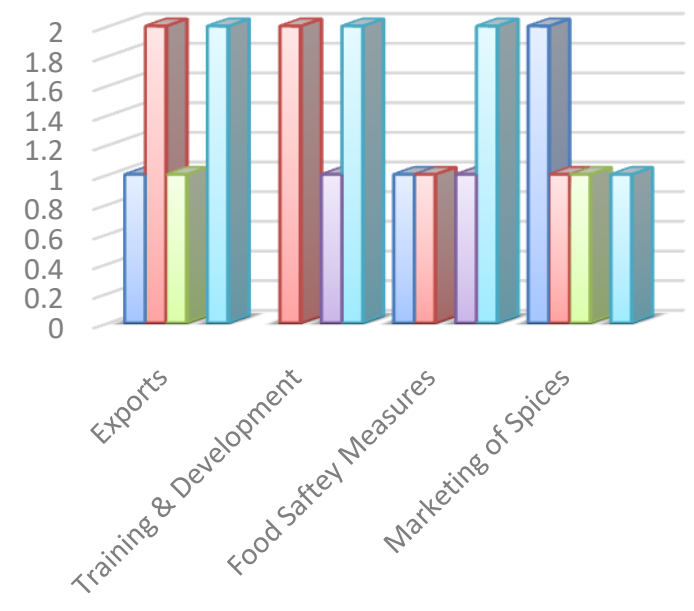

Majority respondents (i.e. 50\%) do attend the training sessions occasionally whereas $12 \%$ of them attend it regularly, another $12 \%$ attend in frequently and another $12 \%$ never attend the trainings.

From the data it can be inferred that $25 \%$ companies exports increased by 6-15\% and above $60 \%$, other $12 \%$ companies exports increased by $0-5$ \& $16-15 \%$ resp. $25 \%$ companies training and development costs increased by $6-15 \%$ and above $60 \%$ whereas $12 \%$ companies training cost increased by 30 $60 \%$. $25 \%$ companies food safety costs increased by above $60 \%$ \& other $12 \%$ companies food safety costs increased by $0-15$ \&30-60\% resp. $25 \%$ companies marketing costs increased by $0-5 \%$, whereas $12 \%$ companies training cost increased by $6-30 \% \&$ above $60 \%$ resp. 
Registration and Support

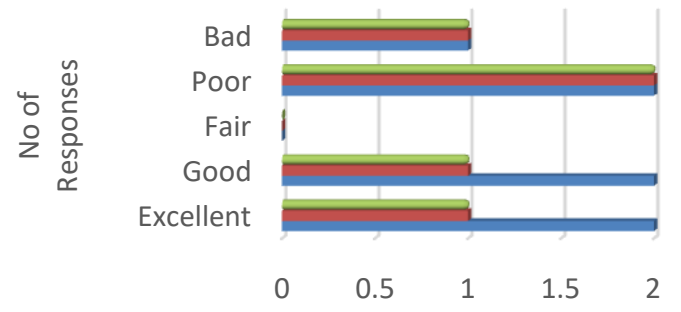

Packing, Development \& Bar coding for promoting spices and spices production

n Printing promotional literatures/ brochures

- Sending business samples abroad
$25 \%$ exporters feel the assistance they receive from the spice board for sending the business samples abroad is excellent/ good whereas another 25\% feel it is poor/ bad. Majority of exporters feel that the assistance they receive from the spice board for printing the brochures is poor/ bad, whereas $12 \%$ find it satisfactory. Majority of exporters feel that the assistance for barcoding poor/ bad. How Often Do You Attend The Training Session Or Seminars Offered By The Spices Board Or Any Other Organization Dealing In Exporting Issues?

Rate Your Satisfaction towards the Following Programs Initiated By the Spices Board

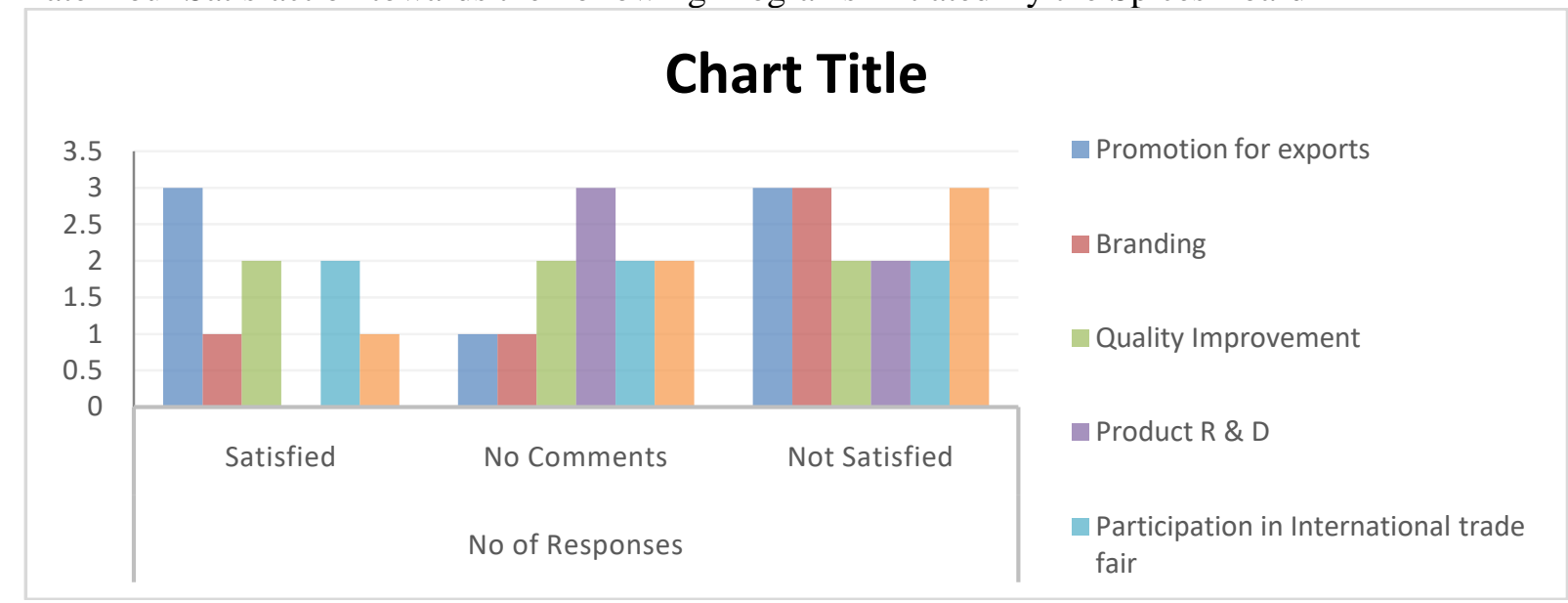

After the interpretation of the data it was found that $38 \%$ respondents were satisfied whereas another $38 \%$ was also not satisfied Promotional programmes of spices board. Majority were not satisfied by branding programms and in assistance for purchase of brands, Majority wished not to comment the assistance in product R\&D. $1 / 3^{\text {rd }}$ of the people were satisfied, while another $1 / 3^{\text {rd }}$ were not satisfied and the other $1 / 3^{\text {rd }}$ choose not to comment about the Quality improvement and participation in international trade fairs.

The Major Constraints for Exports of Spices

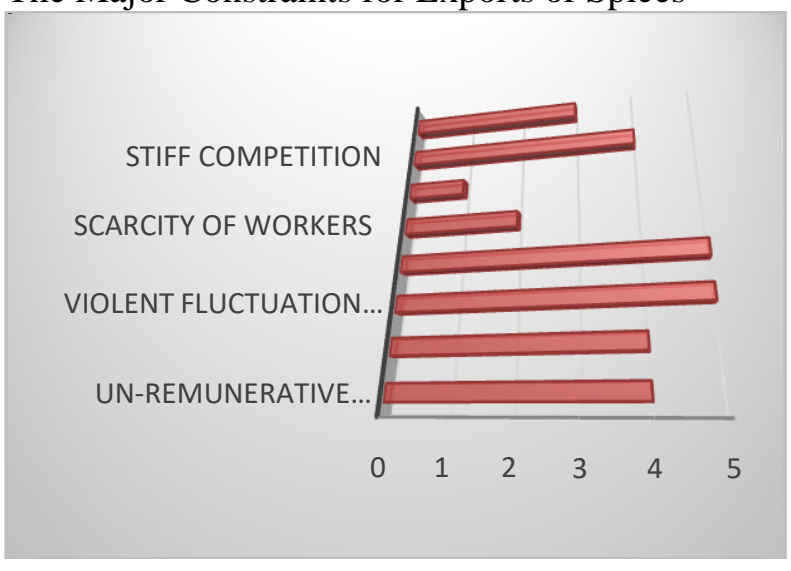

Majority $(55 \%)$ of the respondents felt violent fluctuation in prices Drought, incessant rains, diseases in plants were the major constraints, whereas $44 \%$ felt Un-remunerative selling price, High cost of production Stiff competition were also prominent constraints. 
Measures (Policies) Taken By The Government Of Kerala

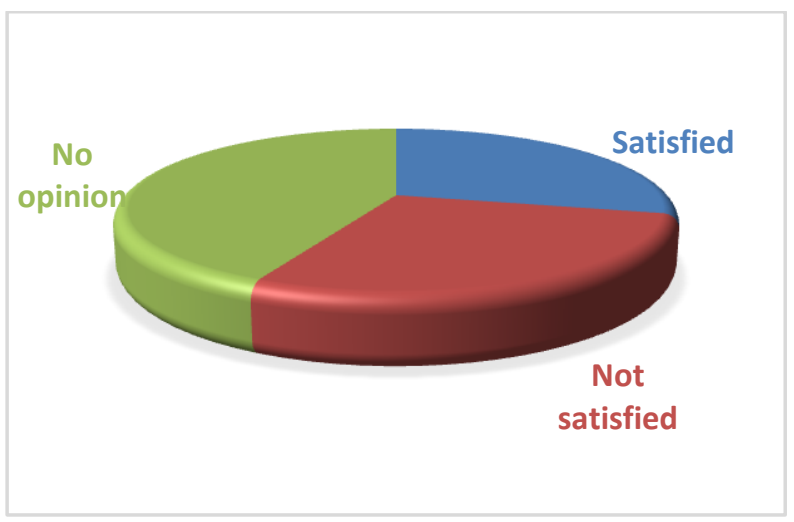

Of the total respondents, majority (37\%) were not satisfied with the measures taken by the government whereas $25 \%$ were satisfied and other $25 \%$ choose to remain indifferent.

Policies That Should Be Introduced That Would Help Exporter

Only $25 \%$ of respondents choose to answer this question, according to them there should be policies on Labour laws, Bank financing, operational costs. They also pointed out that there is reduction in the trade promotion and policy awareness programms that were previously conducted by the spices board. Some also pointed out the unacceptable behavior of government officials.

\section{Findings:-}

* From the analysis of secondary data it was found that the exports of Chillies has a constant growing trend, whereas Pepper, Turmeric, Ginger, Coriander, Cumin, Curry Powder \& Seed spices have good opportunity of future growth.

* Based on the analysis of questionnaire it is inferred that USA \& UAE are the top preferred exporting location.

* From the study it can be inferred that there would be a surge in exports from Kerala in coming years as majority of manufacturing companies plan to begin exporting in next 1-3 years.

* Majority of the manufacturers have adequate production capacity, staff, \& resources but lack knowledge about the export regulation \& preferences.

* Majority of the manufacturers have never approached the agricultural department or the spices board but they expect the government to train interested spice growers.

* Manufacturers expect the government to implement uniform organic certification process whereas exporters want government to introduce policies on labour laws \& bank financing.

* Majority of the exporters are the holders of spice board certificate logo or brand registration $\&$ occasionally attend the training provided by the board, However majority of them are not satisfied with the assistance they receive from the spices board for Packing, Sending Samples, Printing literature, Barcoding etc.

* Violent fluctuation in prices, Drought, incessant rains, Diseases in plants, Un-remunerative selling price, High cost of production \& Stiff competition were prominent constraints faced by exporters and manufacturers.

\subsection{Conclusion:-}

$>$ Based on types, the spices and seasonings market is led by the pepper segment, followed by the capsicum segment. The use of pepper as a key ingredient in various cuisines, it is also used to treat fever, asthma, cough, dyspepsia, flatulence, and arthritis. This has led to an increased demand for pepper for Ayurvedic medicines. Thus it has an opportunity of future growth.

$>$ Untapped regions have new growth opportunities, there is high growth potential in emerging markets as the market is driven by factors such as increased demand for snacks \& convenience food and meat \& poultry products furthermore, factors such as increasing 
disposable income and rapid urbanization have also increased the demand for spices and seasonings,

$>$ Increasing instances of unfair trade practices such as adulteration are expected to restrain the market growth. Though the prices of spices and seasonings are highly volatile and vary across different regions, the market is expected to grow at a significant rate.

\section{Bibliography}

Aiyadurai. (1989). Progress of spices. Indian Central Spices and Cashewnut committee.

Alagappan. (2001). Production of pepper in India, a global perspective.

Azhar Ali Farooqi, B. S. (2005). Cultivation of Spice Crops.

Benjamin, M. (1988). Problems and prospects of Exports of Spices Oils and Oleoresins From India.

Cherian. (1991). Performance of India's export trade in spices.

George. (1998). Cardamom development past and present.

Indim. (2002). Indian cardamom handicapped by poor productivity.

Indira, B. \&. (2002). Indian Spices Challenges Ahead.

Jacob, B. (1985). Export Development of Kerala.

Jose. (1978). Problems and Prospects of India's major spices.

Joseph, B. (2003). Trends in area under cultivation and productivity of ginger in Kerala.

Kuruvilla, T. a. (2004). Development and Application Of Ayurvedic Spices.

Leu, A. (2010). Organic Farming and Climate Change.

Mary. (1996). Development and trends in pepper export from Kerala.

Menon, G. (1988). Processing, procurement and marketing of pepper with special reference to cooperative sector.

Nair, G. (1987). Problems and prospects of marketing cardamom in India and abroad.

Peter. (1999). Making of the global leader.

Prakash. (2008). Farm Crisis in Idukki.

Pruthi. (2001). Minor Spices and Condiments - Crop Management and Post harvest Technology.

Sajad, M. (1987). India's cardamom trade with Middle East.

Sharma. (2006). Prospects of India's Pepper Trade.

Sivadasan. (1998). Action plan/ proposals to evolve suitable strategies .

Sreekumar. (1990). The test launch study of Milma Cardamom Milk.

Sreekumar. (1999). World trade in spices- Import and Re-export of pepper.

Sreekumar, S. a. (2007). Guatemalayan way of cardamom growing.

Sujitha, S. (2004). Production Trends in Vanilla.

Suresh. (1984). Economics of Cardamom plantation in Kerala.

Swaminathan. (1985). Trends in the area, production and export price of cardamom in Kerala, Tamilnadu and Kamataka.

Thakamani. (2009). Organic Spices.

Thampy, S. (1998). Organic the only way.

Thampy, S. (2000). International Trade.

Thomas. (1984). Standardization techniques for retention of green colour in pepper. 